\title{
CEUTA, UNA CIUDAD FORTIFICADA
}

José Luis Gómez Barceló

Es Ceuta, desde su más remota antigüedad, plaza fortificada de importancia, quizá no tanto por la envergadura de sus defensas como por su ubicación geoestratégica, la misma que es responsable de su existencia misma como ciudad.

Una mirada al mapa pone de manifiesto su singular situación, en la orilla norte del Estrecho de Gibraltar, estribo de un imaginario puente entre Europa y África, puerta de comunicación entre el Mediterráneo y el Atlántico y, desde hace ya varios siglos, observatorio privilegiado de los movimientos de tres naciones: España, Marruecos y Gran Bretaña.

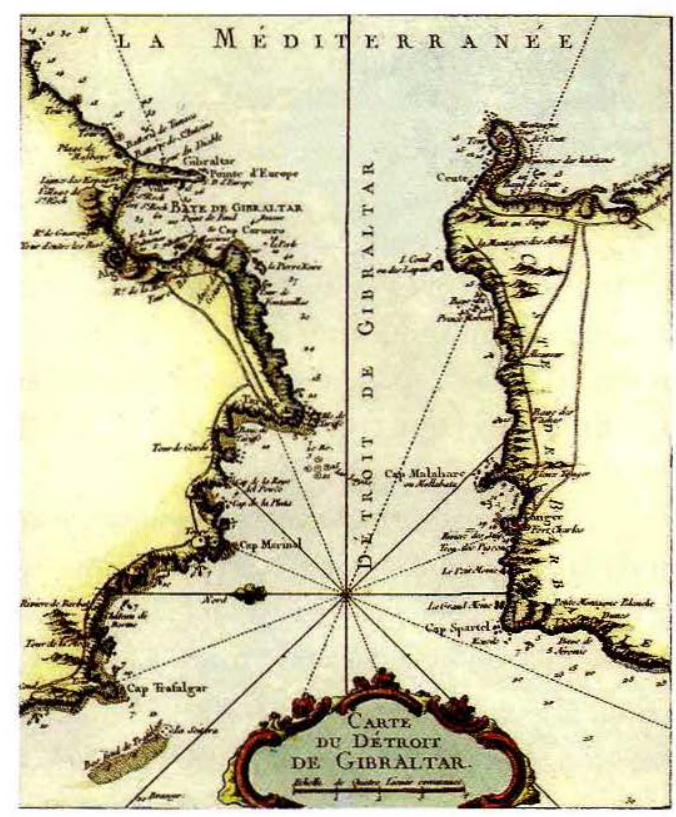

Carta del Estrecho de Gibraltar, Col. Empresa de Alumbrado Eléctrico de Ceuta.

\section{EL NACIMIENTO DE LA CIUDAD}

El actual territorio que ocupa Ceuta, con 19 kilómetros cuadrados, comprende en su parte occidental la zona continental, que se va estrechando, hacia el este, hasta constituir un istmo transformado, quizá desde época bizantina, en una fortaleza cuadrangular, para volver luego a ensancharse, ganando altura por las estribaciones de la Almina hasta finalizar esta península en el monte Hacho, coronado por su fortaleza. 


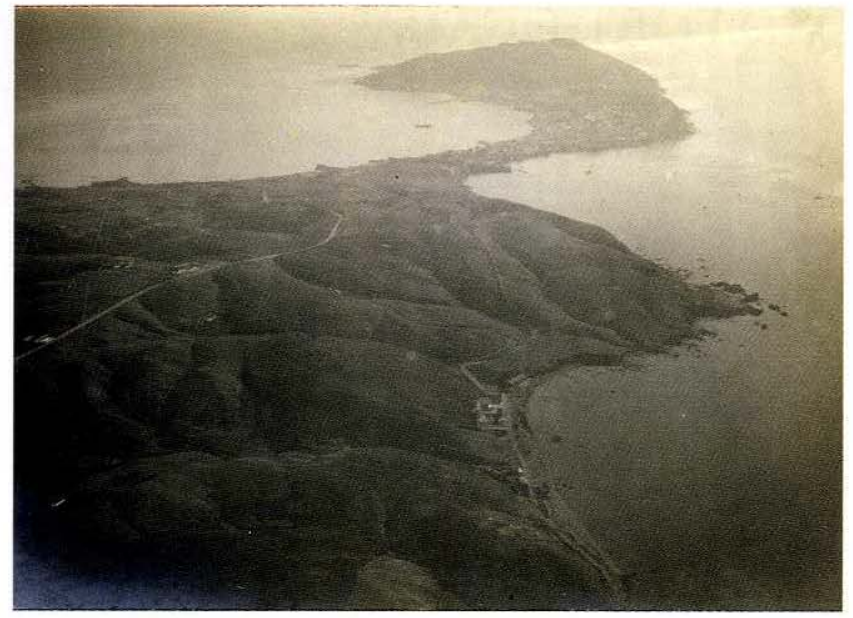

Vista aérea de Ceuta hacia 1906, Col. Del autor.
No vamos a hablar aquí de los asentamientos prehistóricos descubiertos en Benzú y fechados 270.000 años antes de Cristo ${ }^{1}$, pero sí es obligado decir que el germen del núcleo urbano está hoy ya probado que se encuentra en un asentamiento fenicio datado en el 700 a.C. Un yacimiento que se ubica justamente al lado de la entrada principal de la Catedral de Ceuta ${ }^{2}$.

La consolidación de la urbe se producirá en época romana. Desde el II a. C. hasta el IV después de $\mathrm{C}$. al ponerse en funcionamiento una gran industria dedicada al salazón del pescado, rodeada y defendida por un importante muro, que fue descubierto en las excavaciones del paseo de las Palmeras en 1906-1998³ Son estas las primeras fortificaciones que conocemos en la Ciudad.

La factoría de salazones desaparece en el siglo IV, al tiempo que lo hacen en toda la ruta mediterránea. En esa misma época se construye una basílica extramuros, cuya primera defensa estaría en la base de la muralla califal, como demuestran las piletas de salazón halladas en el muro este, hoy visibles en la calle Queipo de Llano ${ }^{4}$.

Es en esta época, de dominio bizantino, cuando se consolidan las defensas de la población y se construyen importantes edificios ${ }^{5}$. Los arqueólogos identifican hoy el

1. Ramos Muñoz, J. y Bernal Casasola, D. El Proyecto Benzú. 250.000 años de historia en la orilla africana del Círculo del Estrecho. 30 preguntas y 10 opiniones, Ciudad Autónoma de Ceuta y Universidad de Cádiz, Madrid, 2006.

2. Hita Ruiz, J. M. y Villada Paredes, F. Un decenio de arqueología en Ceuta 1996-2006, Ciudad Autónoma de Ceuta, Ceuta 2007.

3. Bernal Casasola, D. y Pérez Rivera, J.M. Un viaje diacrónico por la historia de Ceuta, Ciudad Autónoma de Ceuta, Ceuta 1999.

4. Fernández Sotelo, La muralla romana de Ceuta, Ciudad Autónoma de Ceuta, Ceuta 2004.

5. Gozalbes Cravioto, E. Los bizantinos en Ceuta (siglos VI-VII), Caja de Ahorros y Monte de Piedad, Ceuta 1986. 
cuadrilátero que formaron las murallas norte y sur y las primitivas escarpas del este y el oeste, con las califales ${ }^{6}$, seguramente cimentadas en las anteriores.

\section{LA FORTIFICACIÓN CALIFAL}

Las crónicas medievales, así como las prospecciones y excavaciones arqueológicas, han confirmado la importancia del proyecto defensivo califal. Si bien es cierto que los restos de muralla norte son escasos -la puerta de Santa María y torres cercanas- $\mathrm{y}$ menos aún los de la muralla sur, al este apareció hace años un buen resto de muralla, hoy puesta en valor, mientras que al oeste, embutida entre la escarpa del foso real del siglo XVI y las

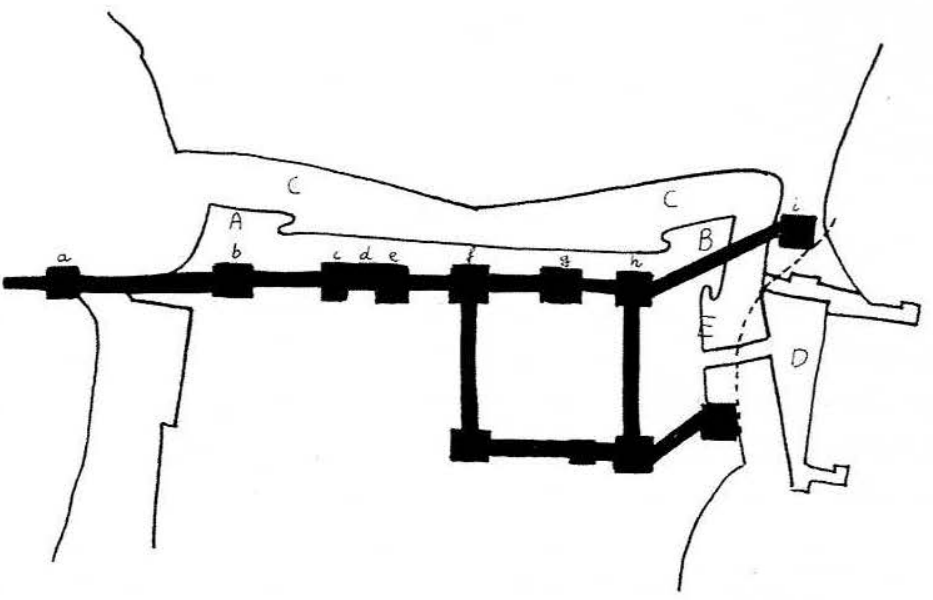

Reconstrucción del alcázar medieval de Ceuta sobre las murallas del siglo XVI de Carlos Gozalbes Cravioto. bóvedas del XVIII han dado una grata sorpresa a los investigadores. En 2004 durante la celebración de las I Jornadas de Fortificaciones convocadas por la Fundación Foro del Estrecho apareció casi intacta la antigua puerta de la ciudad y estructuras a soga y doble, triple y hasta cuádruple tizón con alrededor de dieciséis metros de altura ${ }^{7}$.

6. Hita Ruiz, J.M. y Villada Paredes, F. "En torno a las murallas de Ceuta. Reflexiones sobre el amurallamiento de Septem Fratres y la cerca omeya de Sabta”, Actas de las I Jornadas de estudio sobre fortificaciones y memoria arqueológica del hallazgo de la muralla y puerta califal de Ceuta, Fundación Foro del Estrecho, Ceuta 2004.

7. Hita Ruiz, J.M. y Villada Paredes, F. "Informe sobre la intervención arqueológica en el Parador de Turismo Hotel "La Muralla" de Ceuta", Actas de las I Jornadas de estudio sobre fortificaciones y memoria arqueológica del hallazgo de la muralla y puerta califal de Ceuta, Fundación Foro del Estrecho, Ceuta 2004. 
Los estudios de los arqueólogos han confirmado no sólo las estructuras que ponían de manifiesto alzados del siglo XVI y XVII como los de Africae Nova Descriptio o Civitatis Orbis Terrarum sino también la reconstrucción que sobre los mismos propusiera Carlos Gozalbes Cravioto ${ }^{8}$.

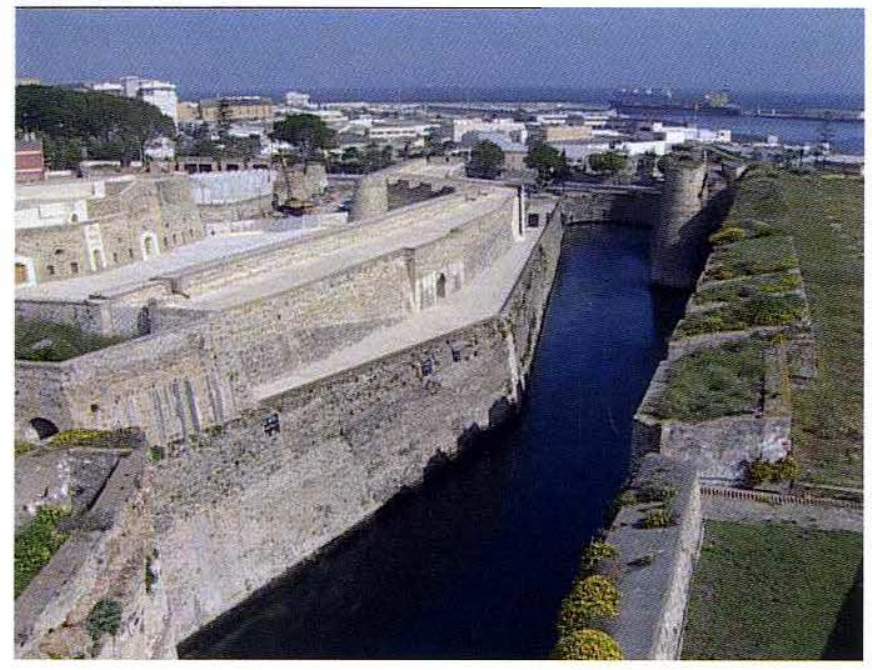

Foso Real con la escarpa a la derecha y la contraescarpa a la izquierda. Foto J.J. Gutiérrez.

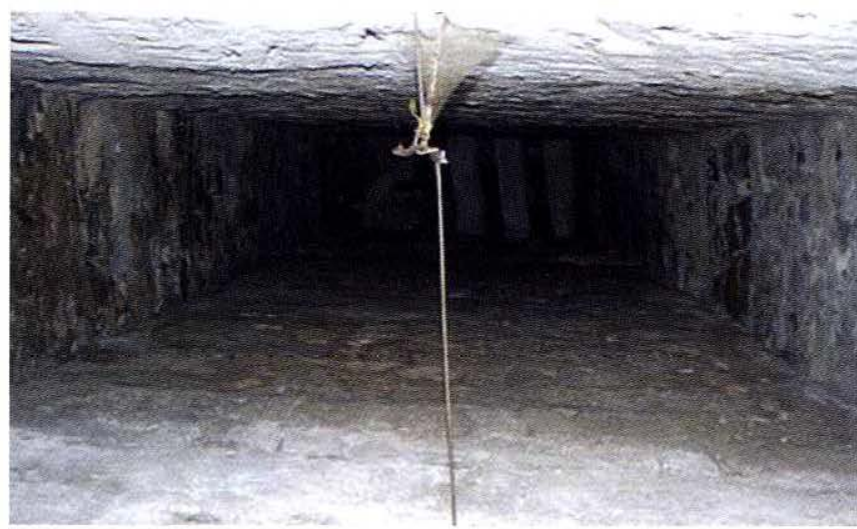

Fragmento de la muralla califal de Ceuta, Foto del autor.
Durante años, creímos que la construcción de la escarpa del foso real, entre 1541 y 1549 había supuesto la demolición de la muralla anterior. Sin embargo, Miguel Arruda y Micer Benedito de Rávena dejaron la enorme construcción califal como refuerzo de la levantada por ellos, quedando más tarde embutida entre esta y las bóvedas proyectadas por Jorge Próspero Verboom en $1724^{9}$.

El hallazgo del año 2004 consistió en la aparición de un lienzo de muralla a soga y doble, triple y hasta cuádruple tizón de dieciséis metros de altura, que vertebraba una salida de ventilación en un túnel que comunicaba la antigua plaza de cuarteles con la caserna ubicada bajo el baluarte del caballero o coracha baja.

8. Gozalbes Cravioto, C. "Las fortificaciones hispano-portuguesas del Frente de Tierra de Ceuta (I), (1550-1640)", Transfretana, n² 2, Instituto de Estudios Ceuties, Ceuta, 1982.

9. Vilar, J.B. y Vilar, M.J. Límites, fortificaciones y evolución urbana de Ceuta (siglos XV-XX) en su cartografía histórica y fuentes inéditas, Ciudad Autónoma de Ceuta, Ceuta 2002, pp. 121 y ss. 
El segundo era una estructura medieval con varios espacios, arcos, torres, una enorme cúpula y una puerta con arco califal, en la que sus alfices continuaban por la torre anexa, estando el hueco de la lápida fundacional en el coronamento de la muralla.

Las fotografías que mostramos son las realizadas durante el descubrimiento de las diferentes piezas descritas. En cuanto al esquema de los espacios presentamos el diseño realizado por el arquitecto Carlos J. Pérez Marín ${ }^{10}$, en los días del descubrimiento.

Los lienzos hallados nos permiten hacernos una idea de la potencia de la

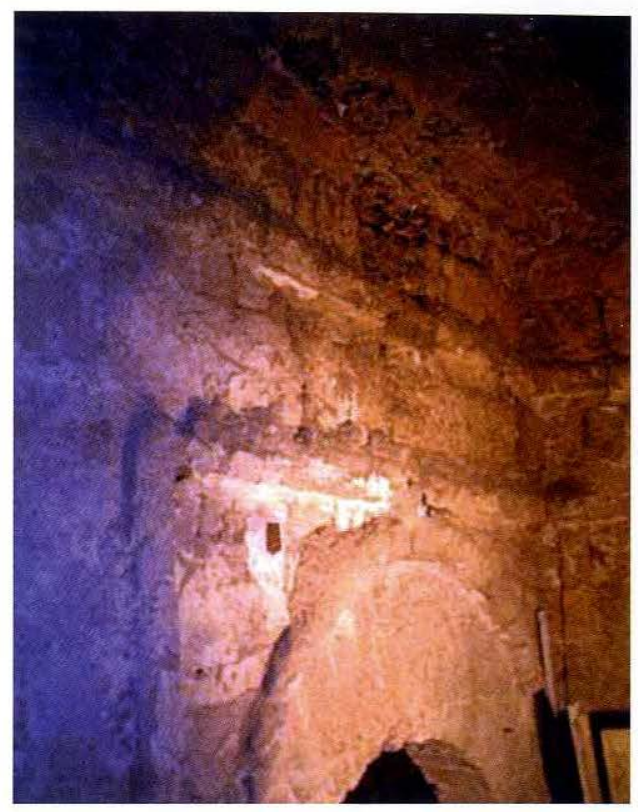

Puerta califal de Ceuta, Foto del autor.

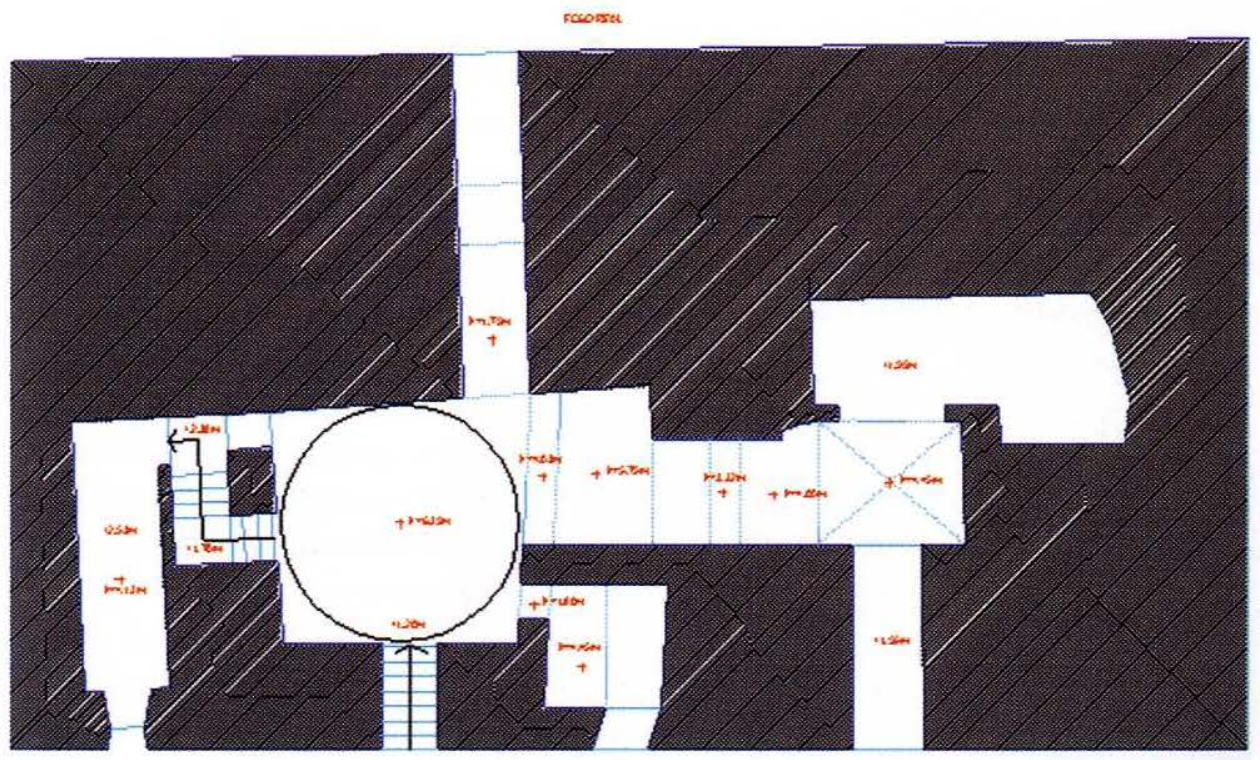

weor

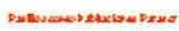

Reconstrucción de la puerta califal de Ceuta por Carlos J. Pérez Marín

10. Agradecemos a su autor el habernos facilitado tan importante documento. 


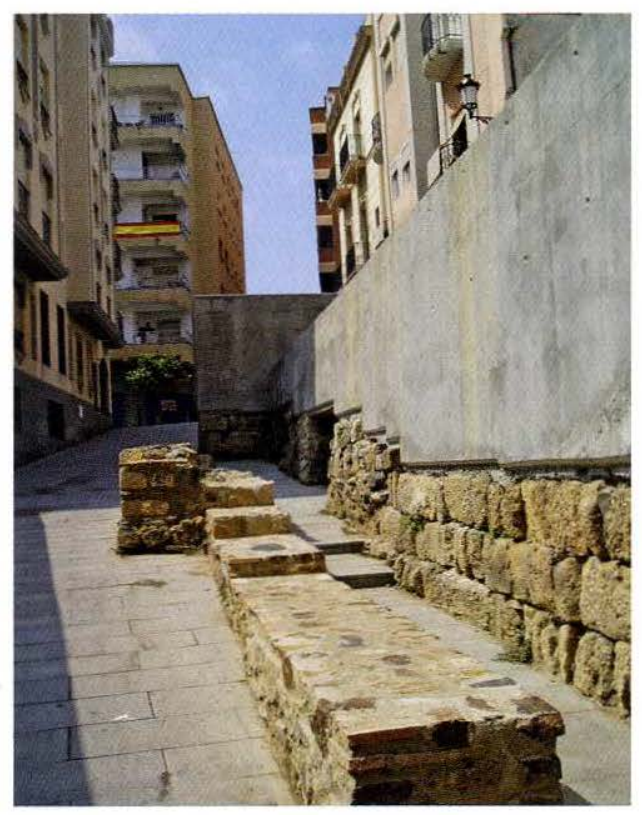

Muralla este del recinto califal, Foto del autor.

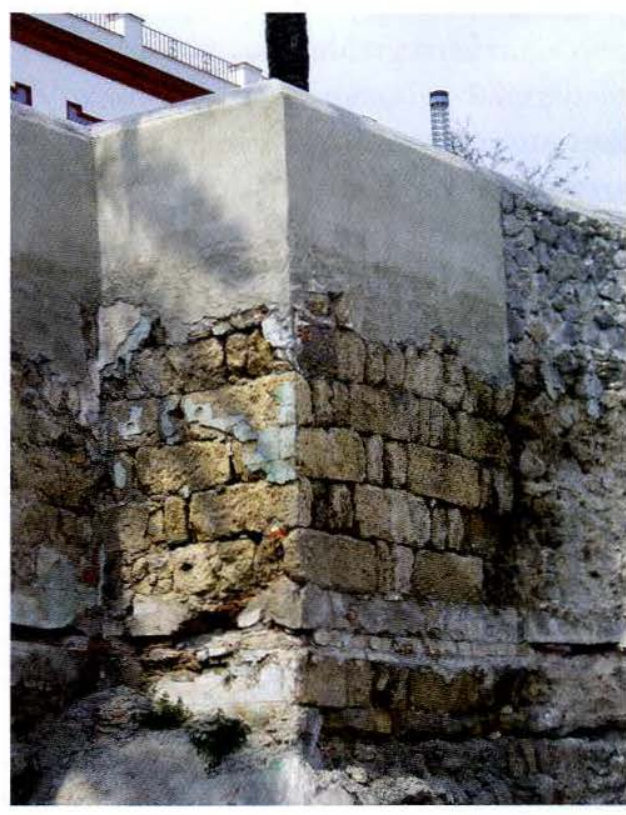

Torre de la muralla norte publicada por Terrasse, Foto del autor.

fortificación, en especial en las dos escarpas, al este y oeste de la población, que en el caso de la primera de ellas ha sido puesta al descubierto, aunque muros y torres tienen poca altura, incluso en la recuperación y restauración realizada por los técnicos de la Ciudad. Una operación que trajo consigo la consolidación, integración en la calle Queipo de Llano - hoy acceso al Museo de la Basílica Tardorromana de Ceuta-, y el recrecimiento volumétrico de su alzado que permite la mejor comprensión del monumento.

Hay que reconocer que los estudios de la fortificación medieval de Ceuta, en especial los del recinto ideado por los tracistas llamados por Abderrahman III, van en paralelo no sólo a las prospecciones y excavaciones, sino también a los procesos de conservación, restauración y puesta en valor de los mismos.

Desde los años 60 se conocía, gracias a los trabajos de Terrasse ${ }^{11}$, la existencia de una torre en la muralla norte del istmo, oculta por diferentes construcciones. En

11. Terrasse, H. "Un vestige des fortifications oméiyades de Ceuta", Al-Andalus, 1962, vol. XXVII. 
el proceso de saneamiento de esta muralla, fruto del desdoblamiento del paseo de las Palmeras, se ha recuperado no sólo esta torre, sino la puerta de salida al mar, conocida desde época portuguesa como de Santa María.

Si la Ceuta anterior a 1912 vivía agobiada dentro de sus murallas, a partir de esas fechas y, sobre todo, entre los años 20 y los 60 , trató de ocul-

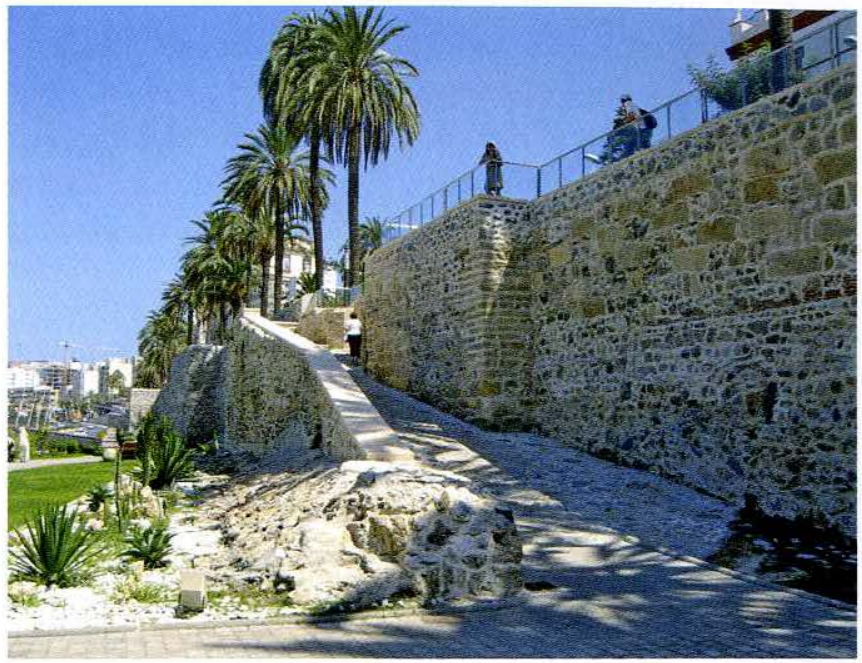

Puerta de Santa María tras la reconstrucción reciente, Foto del autor. tarlas, cuando no de demolerlas. Perdida, incluso, la memoria de muchas de ellas, su recuperación y puesta en valor actual está dando una nueva imagen a la población, no exenta de cierta monumentalidad.

\section{OTROS RECINTOS MEDIEVALES ISLÁMICOS:}

La fortificación califal fue la base para las transformaciones posteriores que en su mayor parte se deben a almorávides y benimerines. Así como las fortificaciones del siglo X son prácticamente indiscutibles en su reconocimiento, en especial por su aparejo, las posteriores requieren mayores estudios. En nuestro caso, algunas torres son modelos almohades clásicos, mientras que el Afrag no presenta problemas de datación ni adscripción.

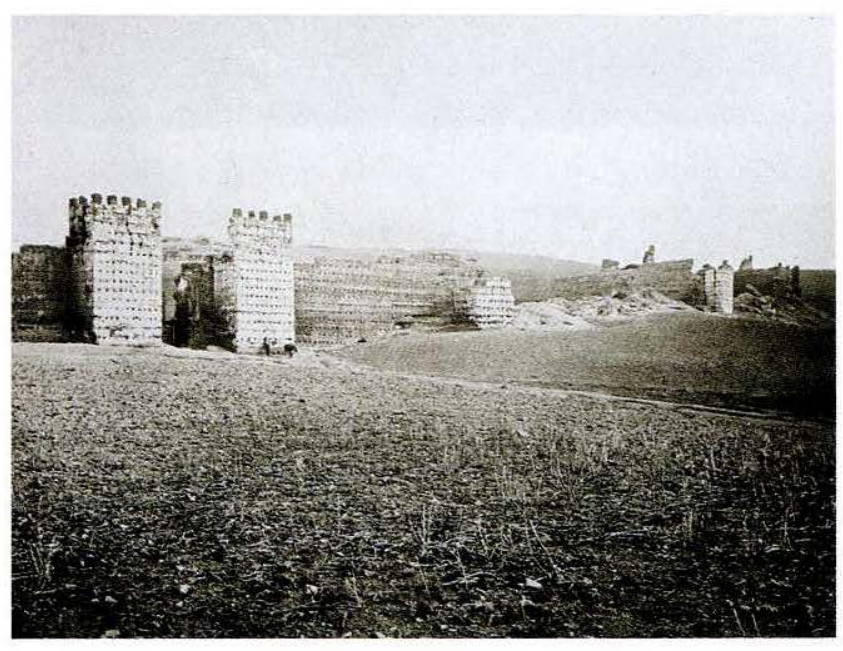

Puerta de Fez y parte de las murallas del Afrag. Foto Wilson y Cía, Col. Arzobispado de Tánger. 


\section{a) El Afrag}

En 1328 se data la construcción del Afrag, un recinto murado exterior a la ciudad, en su parte continental, construido de tapial y del que nos quedan varias torres, lienzos y el acceso occidental del mismo, que recibe el nombre de Puerta de Fez.

Las mejores imágenes del recinto íntegro proceden de Wilson y Cía, la compañía escocesa dedicada a realizar imágenes por diferentes ciudades y países, y se fechan hacia $1870^{12}$. Concretamente la imagen que hemos utilizado corresponde a la colección conservada en el Arzobispado de Tánger.

\section{b) El Hacho}

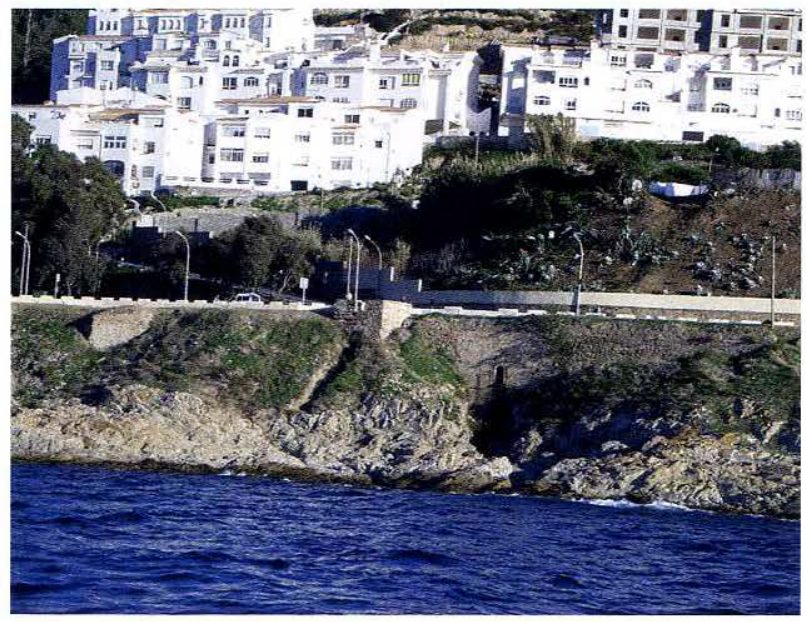

Restos del circuito perimetral de muralla medieval del Hacho, en Torremocha. Foto del autor. mitad del siglo XVIII ${ }^{14}$, que forman el tercero de los amurallamientos.
La fortificación del Monte Hacho supone uno de los retos más interesantes y constantes en la investigación de las defensas locales. Consiste en tres recintos diferentes: En primer lugar un circuito de murallas medievales, con torres cuadradas, en su mayoría de sillarejo, de las que se conservan algunas. En segundo lugar hay una línea de muralla con torres ultracirculares, que las fuentes consideraban ya en ruinas a comienzos del siglo $\mathrm{XVI}^{13}$, para cerrarse con nuevas construcciones abaluartadas en la segunda

12. Garófano, R. Gibraltar, sur de España y Marruecos en la Fotografía Victoriana de G.W.Wilson \& Co., Cádiz, 2005.

13. Piri Reis, Kitab-I Bahriye. Libro para navegantes, Fundación Estatal Fomar, Madrid 207, pp. 191-193.

14. Ruiz Oliva, J.A. "Un modelo de fortificación orográfica: La ciudadela del monte Hacho de Ceuta", "Premio Manuel Corchado 2005", Castillos de España, n 141, Asociación Española de Amigos de los Castillos, Madrid 2006, pp. 54-64 
De estos tres ejemplos, el que nos ocupa en este instante es el recinto inferior medieval, del cual quedan restos visibles tanto en la costa norte como en la sur, desde Torremocha hasta Santa Catalina y entre el Desnarigado, Torrecilla y La Palmera.

\section{c) Torres urbanas}

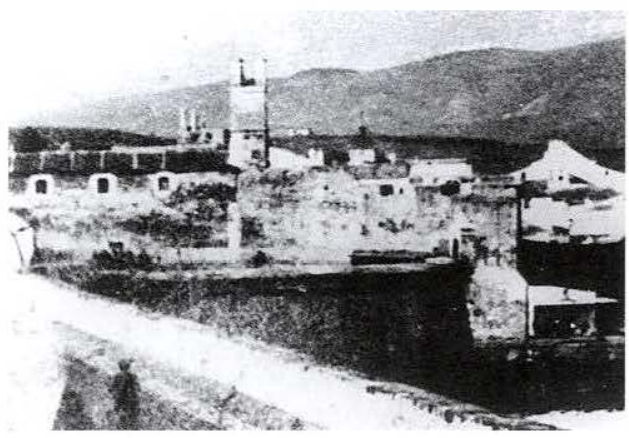

Torre de San Juan de Dios, Archivo General de Ceuta.

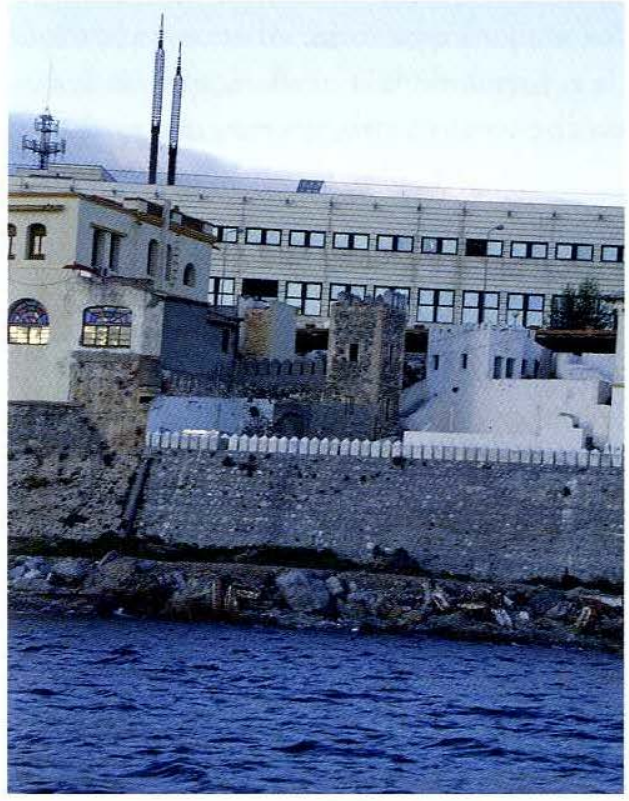

Fuente Caballos, foto del autor

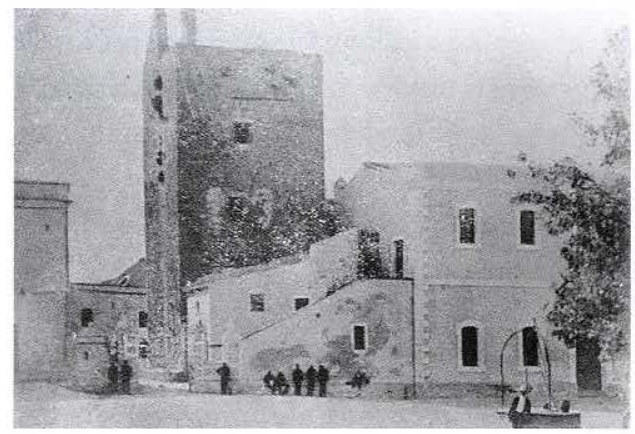

Torre de la Vela o de la Mora, Colección del Autor

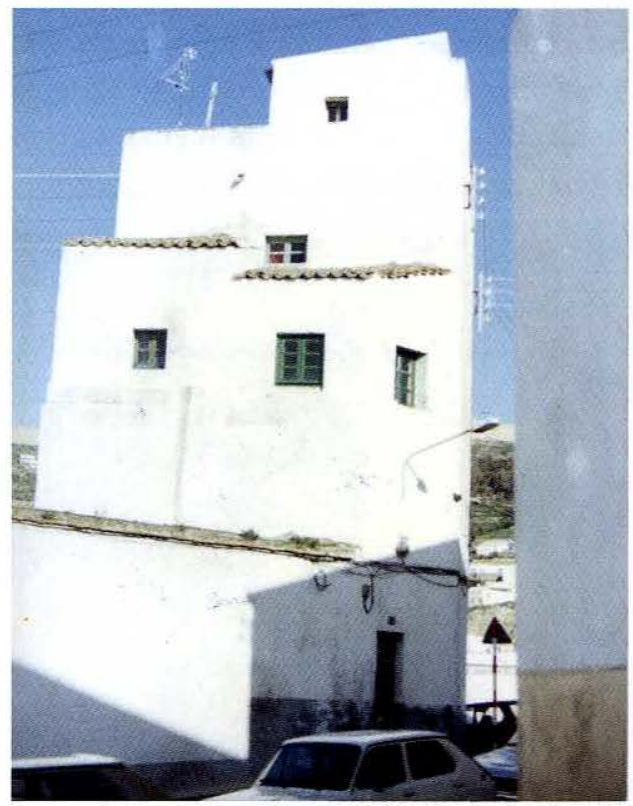

Torre del Heliógrafo, foto del autor.

Son muchos los elementos perdidos de la fortificación medieval, tanto en la ciudad como en la Almina, que eran visibles hace poco más de una centuria. Entre ellas todas las puertas y algunas torres. Entre las más destacadas, las de la Vela o la Mora, 
perteneciente al antiguo alcázar, o la del Rebato o de San Juan de Dios, ambas perdidas en el paso del siglo XIX al XX y que hoy no son más que un recuerdo fotográfico, o ruinas de mayor o menor envergadura en el campo exterior (torres de Fuente la Higuera o Loma Luengo).

Otras sin embargo han sobrevivido, como las construcciones que formaban el acceso por el sur a la Almina, es decir, la puerta de Fuente Caballos, o la torre Almansuria o del Heliógrafo, que muy alterada interior y exteriormente aún se reconoce frente a la ermita del Valle.

\section{LA FORTIFICACIÓN LUSITANA: EL ISTMO}

La conquista de la Ciudad por la Armada de Juan I de Portugal supone una total transformación de una medina islámica en una población cristiana, a lo que habremos de añadir la drástica reducción de su población. Además, la rápida caída de la Plaza en manos de los militares lusos ponía en evidencia la situación de sus defensas, que hubo que fortalecer con rapidez, ante los ataques que se sucedieron a partir de 1418. En esos primeros momentos datamos la reforma de la muralla norte, en la que se han descubierto recientemente troneras de orbe y palo y orbe y cruz, que podemos fechar en la segunda mitad de siglo XV.

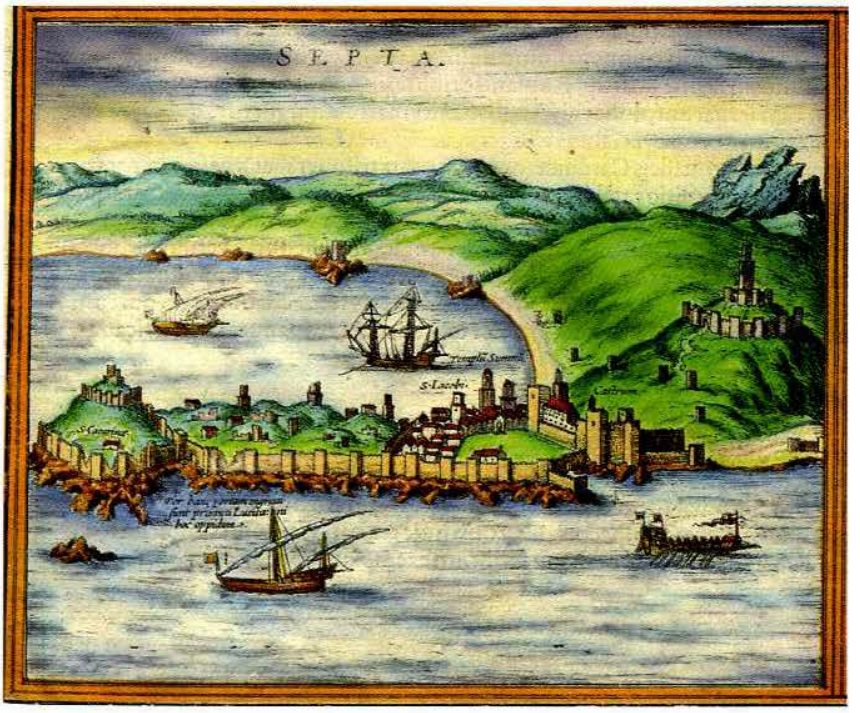

Ceuta en el Africae Nova Descriptio. Colección del Archivo General de Ceuta.
Sin que podamos negar que los nuevos pobladores de Ceuta destruyeron buena parte de los edificios de la Almina, la arqueología ha demostrado a través de hallazgos como las viviendas de huerta Rufino que el desolador panorama que muestran los grabados del siglo XVI es un tanto exagerado.

No obstante, este alzado de 1572 , repetido en diferentes atlas del 
siglo XVI y posteriores ${ }^{15}$, muestra la pervivencia del amurallamiento general de la ciudad y el istmo, así como los recintos superior e inferior del Hacho y el Afrag con su alcazaba interior.

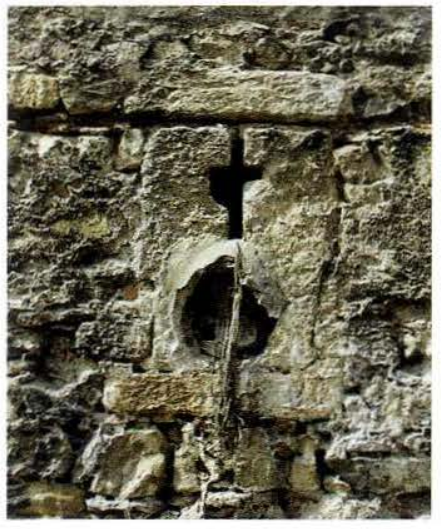

Tronera de cruz y orbe. Foto del autor.

En época de Juan III los ingenieros lusos diseñaron un proyecto consistente en la reducción de la Plaza al istmo, reforzando sus murallas norte y sur y convirtiendo las barbacanas de este y oeste en los fosos seco de la Almina y Real o del agua, respectivamente. A partir del siglo XVII, y sobre la contraescarpa del Foso Real se irán levantando nuevas líneas de fortificación hasta convertir el frente de tierra en un entramado de defensas que harían inexpugnable la población.

Como ya indicábamos, la muralla norte fue reconstruida, mientras que la muralla sur que ha llegado a nosotros está remodelada a finales del siglo XVII entre el torreón de San Miguel y el Foso Seco ${ }^{16}$, estando transformada en su mitad occidental después de la Guerra Civil, con motivo de la construcción del puente Virgen de Africa y la conexión de la avenida Martínez Catena con Independencia.

La pieza fundamental de la defensa es el Foso Real o del Agua, que conforma la primera defensa desde la escarpa de la fortificación. Navegable, permite hoy en día el paso de pequeñas embarcaciones de una bahía a la otra, facilitando las labores a los pescadores locales.

En su día, el foso -que mantiene sus profundidades tal y como muestran

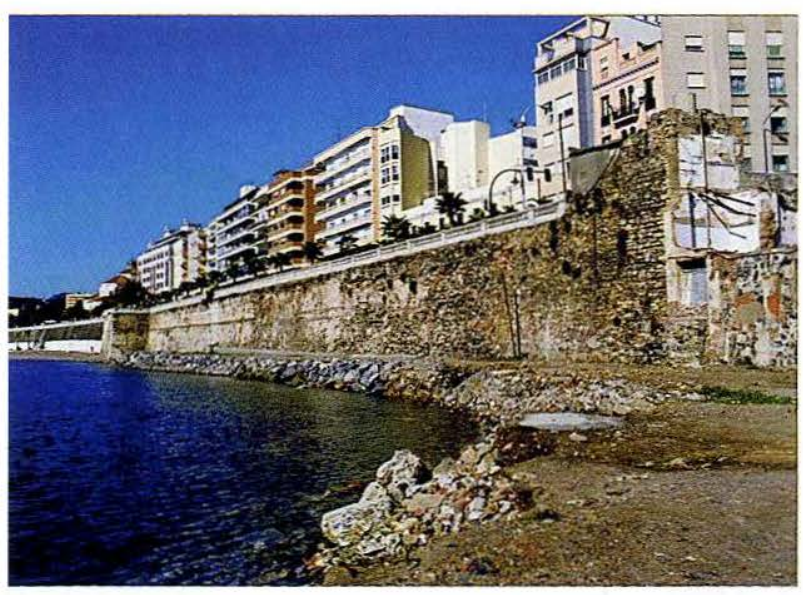

Muralla sur entre San Miguel y el Foso Seco. Foto del autor. 


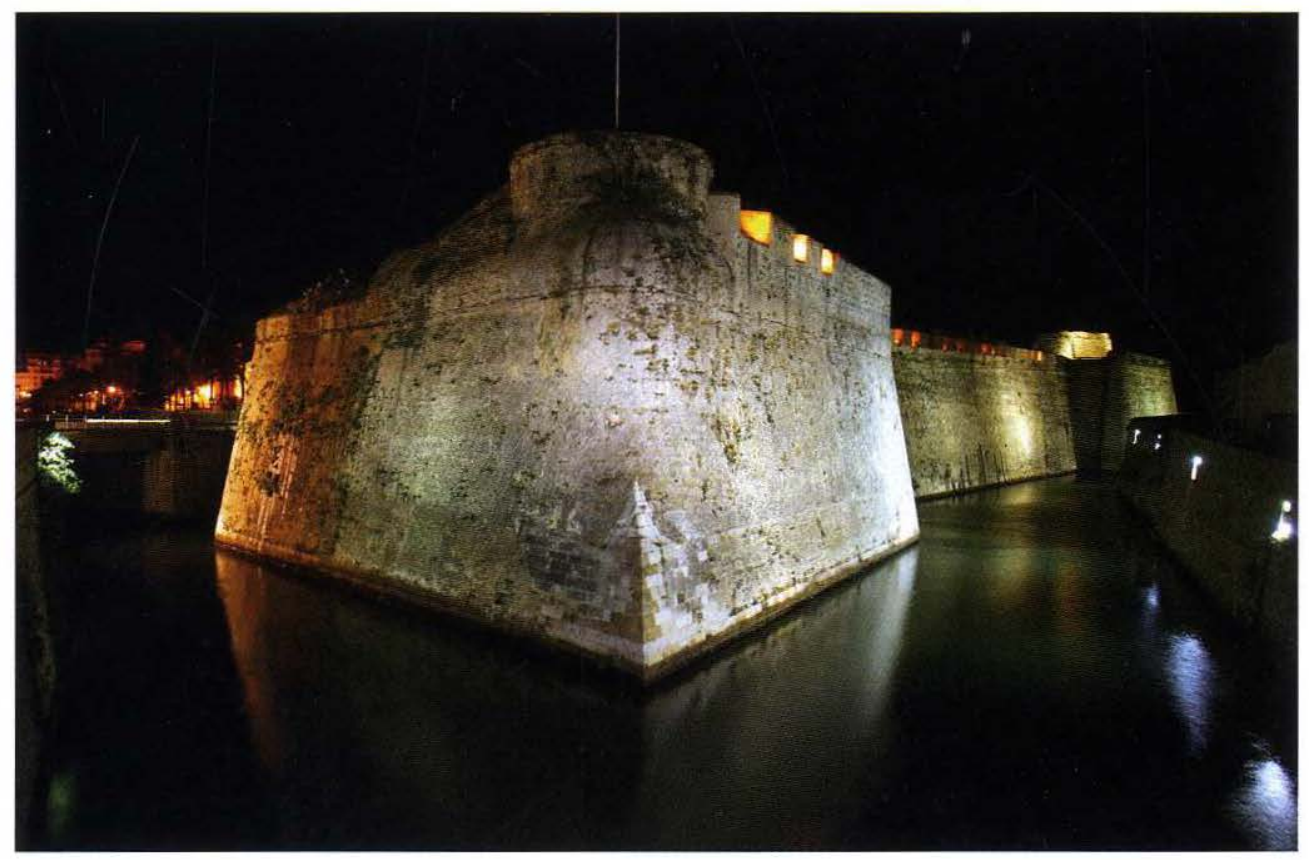

Foso Real de Ceuta. Foto Hamadi.

los planos conservados del siglo XVIII- se salvaba por un puente semilevadizo, mientras que ahora lo hace por tres: el antiguo convertido en fijo, con un sólo ojo adintelado, otro reciente metálico que va en paralelo a éste y un tercero, proyectado por el ingeniero Marciano Martínez Catena y construido entre 1939 y $1940^{17}$.

Mucho menosimponente era el foso de la Almina, en cuya contraescarpa no hubo

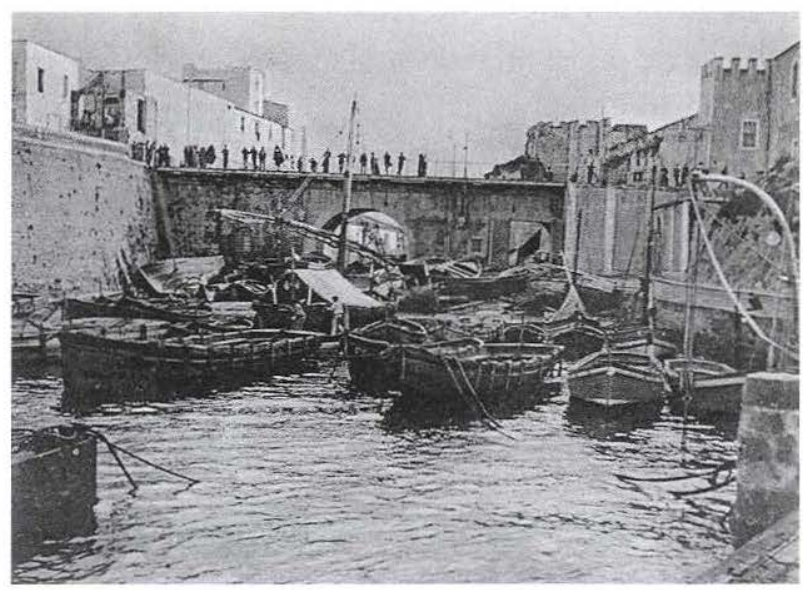

Embocadura norte del Foso de la Almina, con la escarpa con trazas medievales a la derecha y la dársena delante del puente ya fijo. Col. del autor.

17. Junta de Obras del Puerto. Memoria del Puerto de Ceuta, Ceuta 1942. 
más que un gran revellín, aunque modesto en su construcción, con el que se cubría la puerta oriental del istmo. El foso se cerraba en su embocadura sur por un muro y puerta, denominada Boquete de la Sardina, por el que se desembarcaba el pescado para el consumo interno de la población, mientras que en la embocadura norte se ubicaba una pequeña dársena que hacía de modesto puerto para los faluchos que abastecían la ciudad y servían para el correo y comunicación con la Península.

\section{FORTIFICACIONES ESPAÑOLAS: EL FRENTE DETIERRA}

\section{Es común considerar} que el frente de tierra de Ceuta es un proyecto lusitano. Sin embargo, sólo el Foso Real se levantó durante el reinado de la Casa de Avis. Es más, la primera línea sobre la contraescarpa lleva las armas españolas y de los gobernadores de Carlos II. Huelga decir, por tanto, que tanto la tenaza y su falsa braga, la línea de contraguardias y revellines, y la posterior de lunetas y reductos con sus lenguas de sierpe y espigones marítimos ese construyó en tiempos de los Borbones.

El frente de tierra, muy similar al que se proyectó, al tiempo, para la defensa de Cádiz, supondrá un cierre inexpugnable de la Plaza, que traería la tranquilidad tanto de sus habitantes como de sus defensores.

Actualmente, el Frente de tierra no se con-

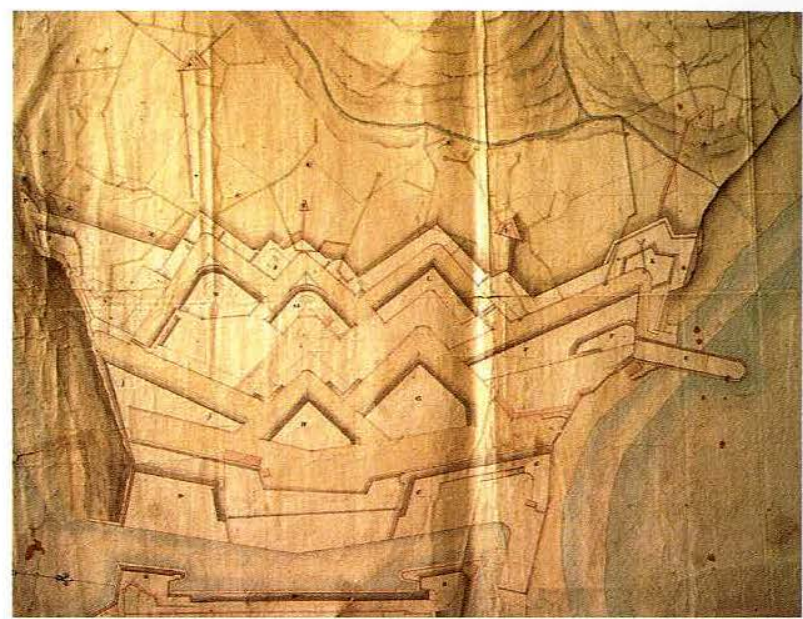

Plano del frente de tierra. Archivo General de Ceuta.

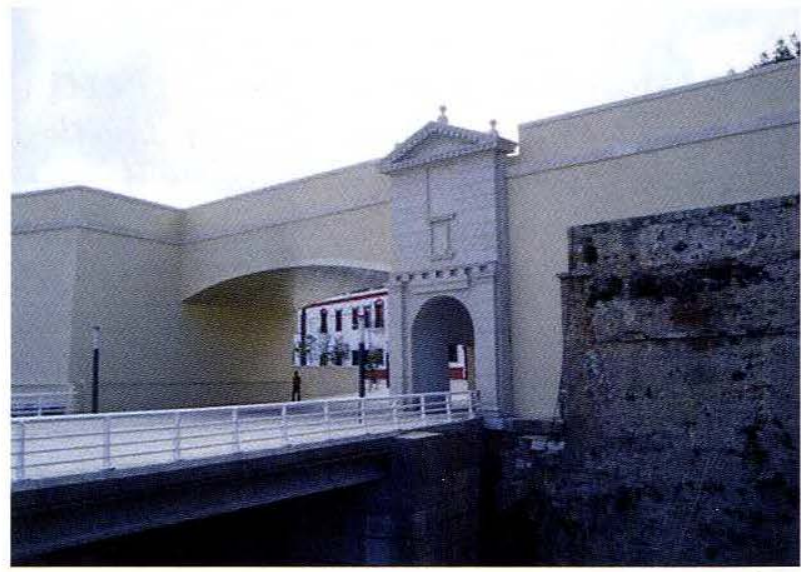

Reconstrucción de la puerta del Puente del Cristo. Foto del Autor. 
serva completo. En su escarpa se ha realizado una reconstrucción volumétrica del baluarte de los mallorquines, así como de la primera puerta o del Puente del Cristo, pero falta el cierre del albacar en ella. En la segunda línea se recortó el baluarte de San Pedro y se demolió la falsa braga, como también se hizo, ya en la tercera, con la contraguardia de Santiago y su caballero. Por último, de la cuarta línea no puede verse más que una pequeña parte de la luneta de San Felipe, embutida en los Jardines de la Argentina, siendo destruido el resto, es decir, lunetas, foso y puertas con sus puentes semilevadizos.

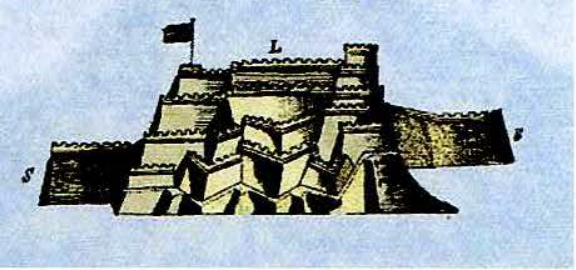

Aspecto del frente de tierra en un alzado del siglo XVIII.

Las obras de recuperación del Conjunto Monumental de las Murallas Reales de Ceuta las ha dirigido el arquitecto Juan Miguel Hernández de León, autor de las reconstrucciones ya aludidas del baluarte de los mallorquines, así como la cortina que lo unía al baluarte de la Bandera y la puerta del puente del Cristo. También fue responsable de la urbanización del foso seco del hornabeque, la recuperación de la contraguardia de San Francisco Javier y la reconversión en espacios museísticos y archivísticos, aún no concluidos, de los revellines de San Ignacio y San Pablo.

La ambiciosa maqueta del proyecto ha dejado para ulteriores fases la recuperación del glacis en la cual pueden, si no reconstruirse, sí indicarse las ubicaciones de las pequeñas lunetas que completaban el frente de tierra.

\section{LA ALMINA: UNA NUEVA POBLACIÓN FORTIFICADA}

Carlos Posac ${ }^{18}$ indicó hace algunos años cómo el refuerzo de la guarnición y el traslado de la población del istmo a la Almina, en parte por la necesidad de utilizar la zona más cercana al frente de tierra para vivienda del ejército, en parte para alejar a los civiles de los efectos del cañoneo enemigo, constituyó una nueva población.

18. Posac Mon, C. "Traslado del emplazamiento de la ciudad de Ceuta por el asedio del Sultán Mawlay Ismail (1694-1727)”, ActasVI Congreso Histórico sobre Nuevas Poblaciones, La Carlota, Fuente Palmera, San Sebastián de los Ballesteros, 11 al 14 de mayo de 1994, pp. 463-474. 


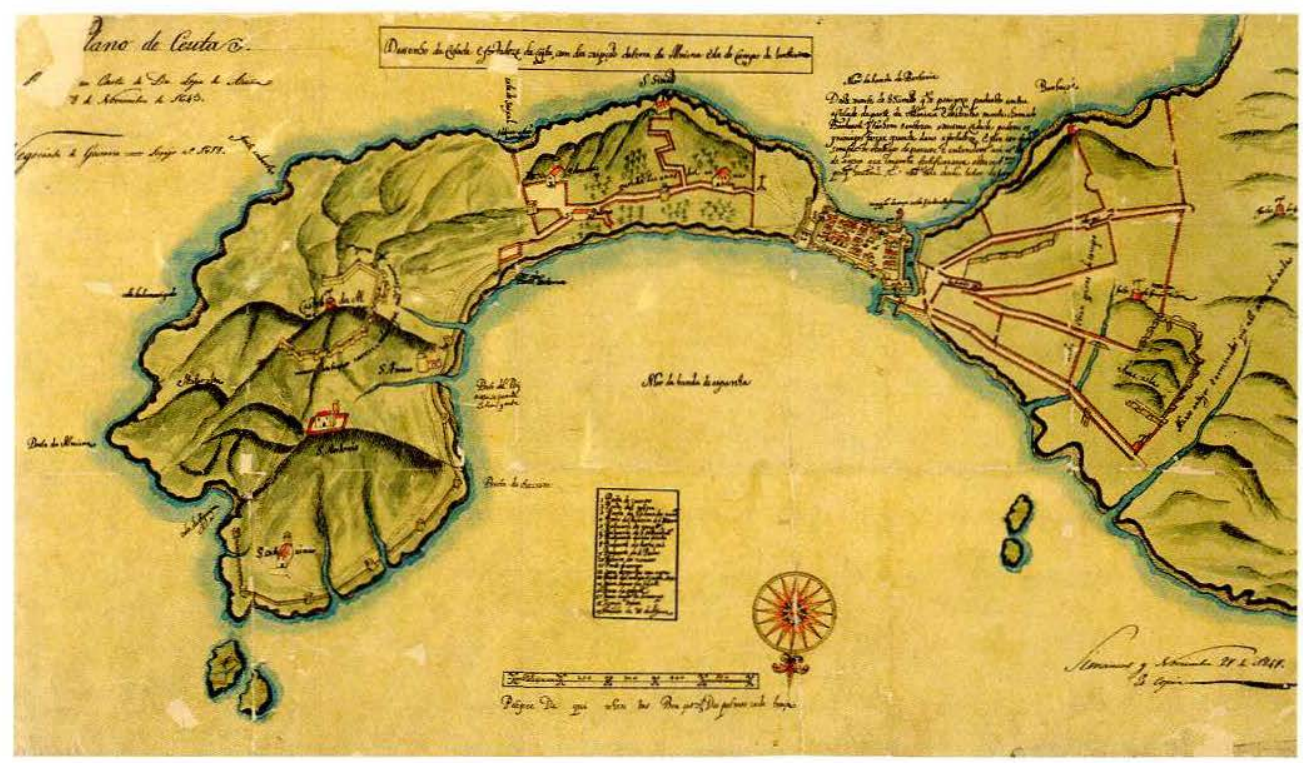

Copia de un plano de la ciudad del siglo XVII de la Colección Aparici.

Del mismo modo, hemos escrito en otros trabajos ${ }^{19}$, como la Almina se urbanizó y fortificó con los mismos principios que se habían puesto en práctica en el istmo: Muralla perimetral, con revellines cubriendo las puertas este -Almansuria o del Valle, ante la cortadura del Valle- y oeste -frente a la puerta y puente de la Almina-, con numerosos puestos de guardia, puertas y rastrillos, que permitían estancar las vías paralelas a las murallas exteriores - caminos de ronda- e impedir, tras un desembarco, la rápida ocupación del terreno.

Hasta comienzos del siglo XIX se estuvo completando y reforzando esta fortificación con nuevas piezas, como el hornabeque levantado con proyecto de Francisco de Orta y $\operatorname{Arcos}^{20}$ entre el foso de la Almina y la puerta de Fuente Caballos, con dos medios baluartes y su cortina.

19. Gómez Barceló, J.L. "La Almina: Una propuesta urbana para la Ceuta de los Borbones", La formación de una ciudad:Apuntes sobre urbanismo histórico de Ceuta,VI jornadas de Historia de Ceuta, Instituto de Estudios Ceutíes, Ceuta 2006, pp. 49-70.

20. Gómez Barceló, J.L. "Francisco de Orta y Arcos, mariscal de campo e ingeniero militar tarifeño", III Jornadas de Historia del Campo de Gibraltar, La Línea de la Concepción, 1994, Almoraima, Algeciras 1995, n 13, pp. 277-290. 


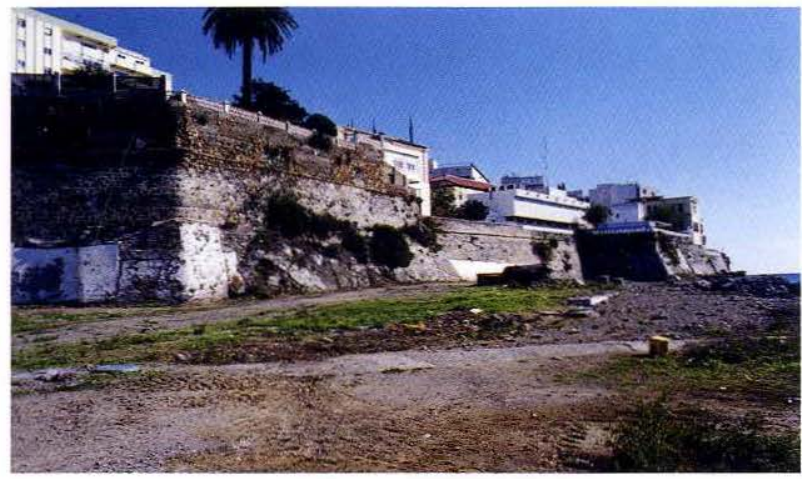

Hornabeque proyectado por Francisco de Orta. Foto del autor.
La recuperación y limpieza de todas estas fortificaciones está dando numerosas sorpresas, ya que las edificaciones anexas, en ocasiones, a estas murallas, minimizaban su importancia y potencia constructiva, no dejando ver ni tan siquiera las inscripciones y lápidas conmemorativas de su construcción.
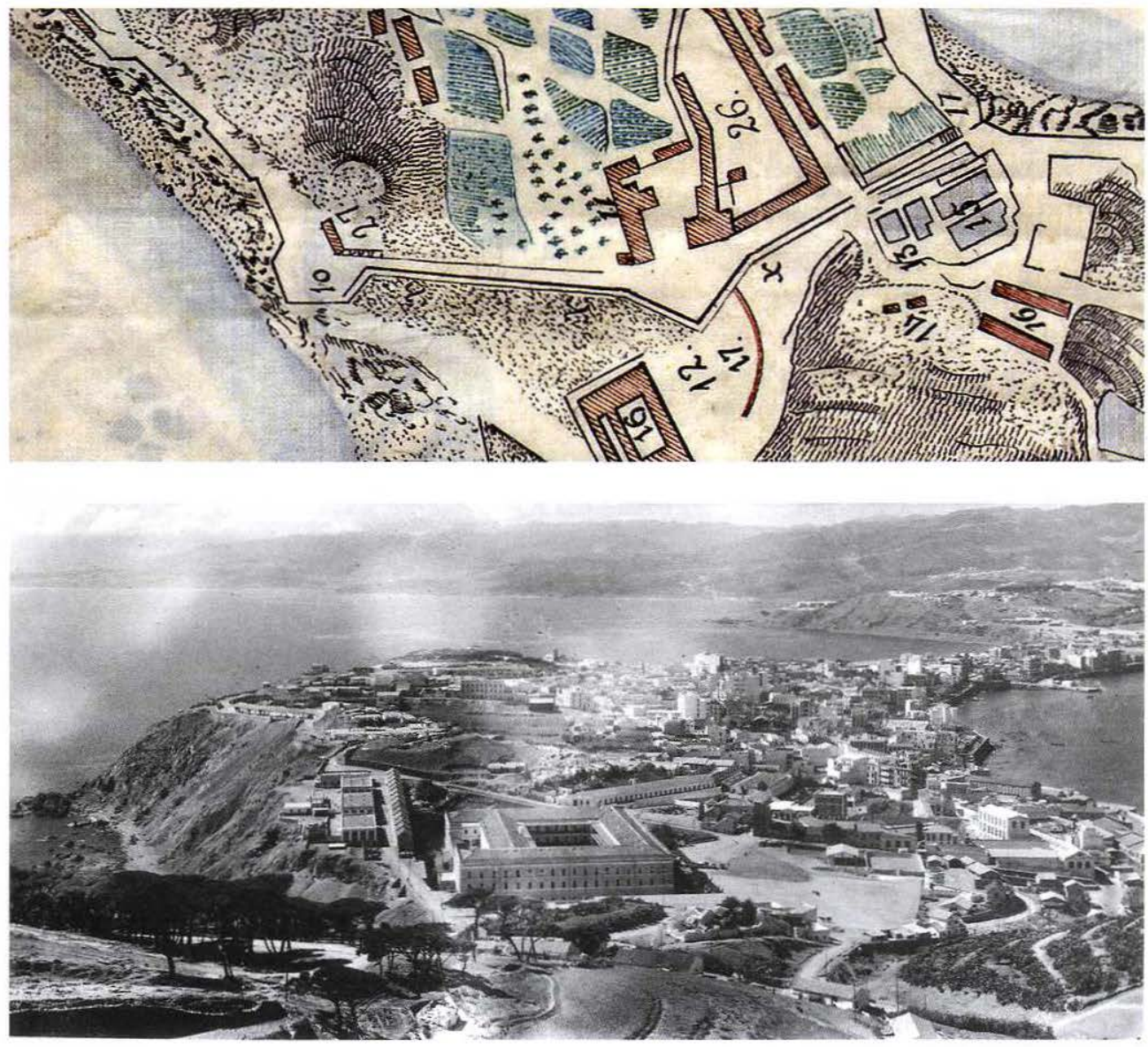

Arriba plano de la cortadura del Valle y debajo imagen de la cortadura en una fotografía de mediados del siglo XX. Col. del Autor. 
Del mismo modo, actualmente resulta difícil comprender piezas como la cortadura del Valle y su antiguo revellín, que superponiendo a planos del siglo XIX fotografías de hace poco más de medio siglo nos hacen entender su envergadura y funcionalidad.

\section{EL HACHO}

Es el Hacho, como ya hemos dicho al comienzo de este trabajo, una de las partes menos conocidas de las fortificaciones locales. Si comentábamos cómo en su círculo inferior tenemos aún numerosos restos del amurallamiento medieval islámico, no lo es menos que entre el siglo XV y el XX se levantaron primero torres - entre el XV y el XVII-, luego pequeños fortines como el del Sarchal y San Amaro - en el XVIII- para en el XIX hacerse las nuevas fortificaciones neomedievales del Desnarigado y la nunca acabada de Santa Catalina, completándose luego con numerosas baterías de costa en la segunda mitad del XIX, que se artillaron y desartillaron ya en la pasada centuria.

No tenemos espa-
cio para extendernos en su estudio, pero ciertamente es necesario abundar en él. Del mismo modo ocurre con la fortaleza del Hacho, que tiene dos partes perfectamente definidas. De un lado una muralla con torres ultracirculares cuyas noticias más antiguas son de comienzos del siglo XVI -Piri Reis ${ }^{21}$ - que, si se ponen en contacto con la descripción de la ciudad que hace Mascarehas $^{22}$ en el XVII, podemos

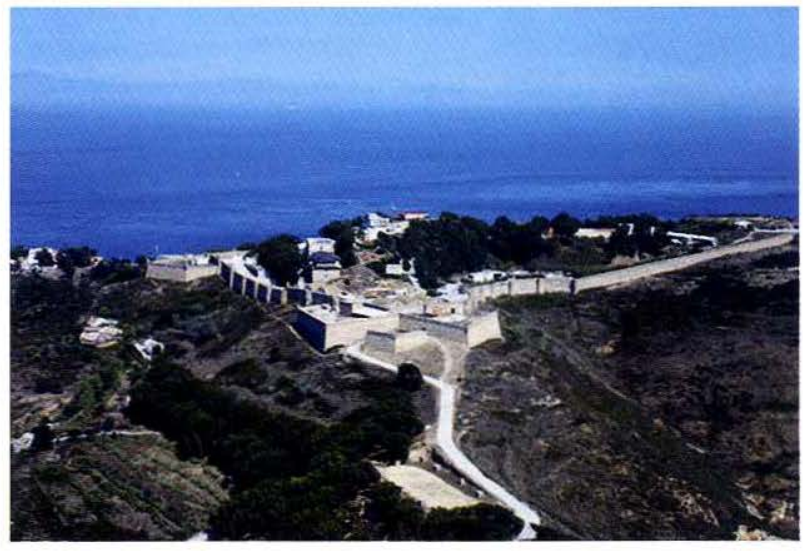

Fortaleza del monte Hacho con la entrada sur-oeste o puerta de Ceuta. Foto J.J. Contreras Garrido.

hablar de una fortificación ya en ruinas entonces. Eso sí, la ruina puede referirse únicamente a su estado de abandono y de no finalización. La datación de esta muralla medieval no está clara. Para unos, siguiendo las fuentes, habría que identificarla con la

21. Piri Reis, op. cit., pp. 191-193.

22. Mascarenhas, J. Historia de la Ciudad de Ceuta, Lisboa, 1918, pp. 12-14. 
fortificación levantada por Almanzor para refugiar a los ceutíes'en caso de necesidad, para otros, en orden a su factura, habría que llevarla al período de dominio lusitano más temprano.

En la segunda mitad del siglo XVIII se retomó la importancia de esta fortale$\mathrm{za}^{23}$, cerrándose según los modos de la fortificación abaluartada, con grandes cortinas de muralla, baluartes y un pastel que protege la denominada Puerta de Ceuta. Además, se construyó en su interior un acuartelamiento que más tarde serviría de prisión.

\section{LOS NEOMEDIEVALISMOS DEL SIGLO XIX}

Pocas ciudades pueden presumir de haber tenido y conservar fortificaciones del siglo XIX. Construcciones con valor defensivo y estilístico, que trataban de dar nuevas respuestas a los problemas defensivos de sus ciudades, mirando no sólo la tradición, sino también la experiencia bélica. Es el caso de Ceuta y Melilla con sus fortificaciones neomedievales, como las denominó, con gran éxito, Luis Mora Figueroa ${ }^{24}$.

La declaración de guerra entre España y Marruecos en 1859 dio lugar a una contienda que vería su fin con el tratado de paz de Wad Ras, firmado al año siguiente. Por él se reconocían nuevos límites a las ciudades de Ceuta y Melilla, obligando a diseñar un nuevo sistema defensivo para los mismos. Tras diferentes proyectos, se determinó hacer una línea de torres circulares con pequeños fosos en su derredor, apoyados por dos fuertes en los extremos de la nueva frontera, y con una serie de acuartelamientos escalonados entre estas defensas y la plaza, para poder guarnecerlas de forma rápida en el momento que fuera necesario.

Así, desde las fortificaciones exteriores, el primer acuartelamiento construido sería el denominado Mil Hombres, convertido más tarde en Hospital Militar O'Donnell, y el segundo la conversión en acuartelamiento del antiguo palacio construido por Alí Riffi en el siglo XVIII conocido como El Serrallo.

El primero de los fuertes levantado, entre el Serrallo y las torres circulares, en la parte sur de la linde, sería el denominado Príncipe Alfonso y, en algunas ocasiones

\section{Ruiz Oliva, op. cit.}

24. Mora Figueroa, L. "Neomedievalismos en fortificaciones del siglo XIX en Ceuta y Melilla”, I Congreso Internacional El Estrecho de Gibraltar, Ceuta, 1987, t. III, pp. 397-496. 


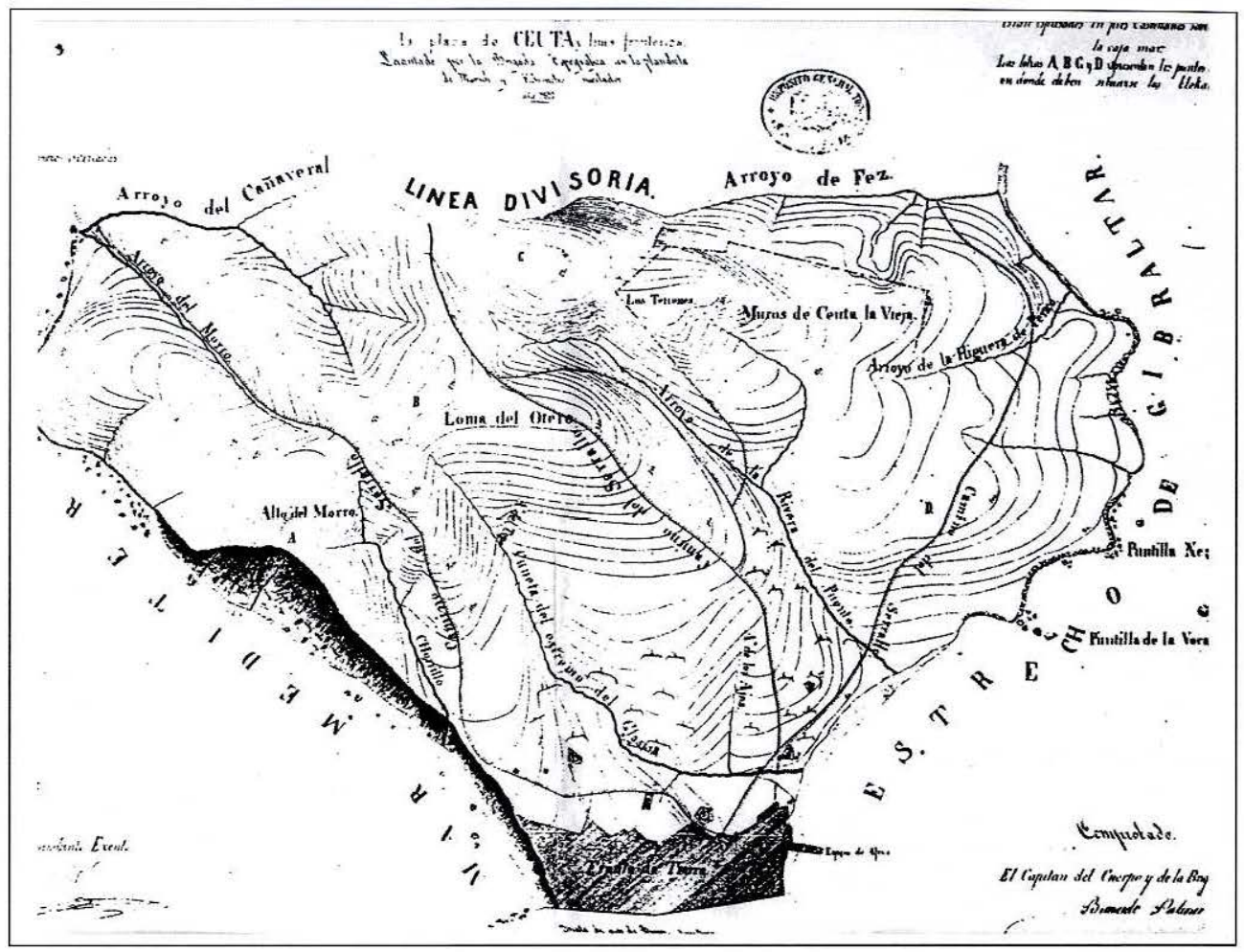

Plano del Campo Exterior de Ceuta con la línea divisoria de 1844, previa a la de 1860 .

Prim, con planos de Paulino Aldaz ${ }^{25}$. Al otro lado, en la parte norte, se optó por una torre de gran diámetro, como la que se colocó en la zona central. La primera recibió el nombre de Isabel II y la segunda el de Benzú, por estar sobre esta bahía.

El resto de las torres neomedievales seguían tres modelos diferentes, todas ellas con los elementos neomedievales que les daban personalidad, como los fosos, las ladroneras, los arcos parabólicos, las troneras y los coronamentos almenados. Como hemos indicado, los más grandes eran los de Benzú e Isabel II, intermedios los de Mendizábal y Aranguren - todos ellos de Federico Mendicuti, aunque realizados en fechas diferentes- y por último, los más pequeños de Piniés, Francisco de Asís, Men-

25. Bravo Nieto, A. "Las nuevas fronteras españolas del siglo XIX: la arquitectura de los fuertes neomedievales de Ceuta y Melilla”, II Jornadas de Fortificaciones, Fundación Foro del Estrecho, Ceuta 2004 (en prensa). 
dizábal y Yebel Ányera, obra posiblemente de Mendicuti, sobre trabajos de Eguía y De Ramón $^{26}$.

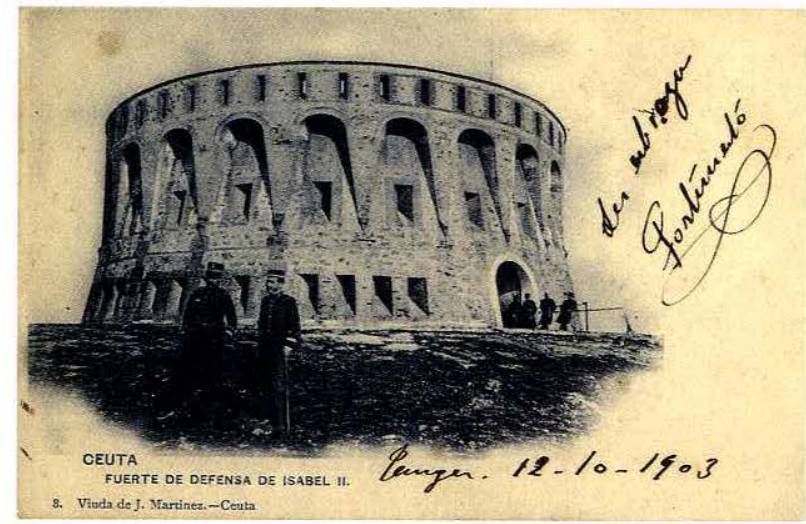

Fuerte de Isabel II, postal de 1903. Col. del autor.

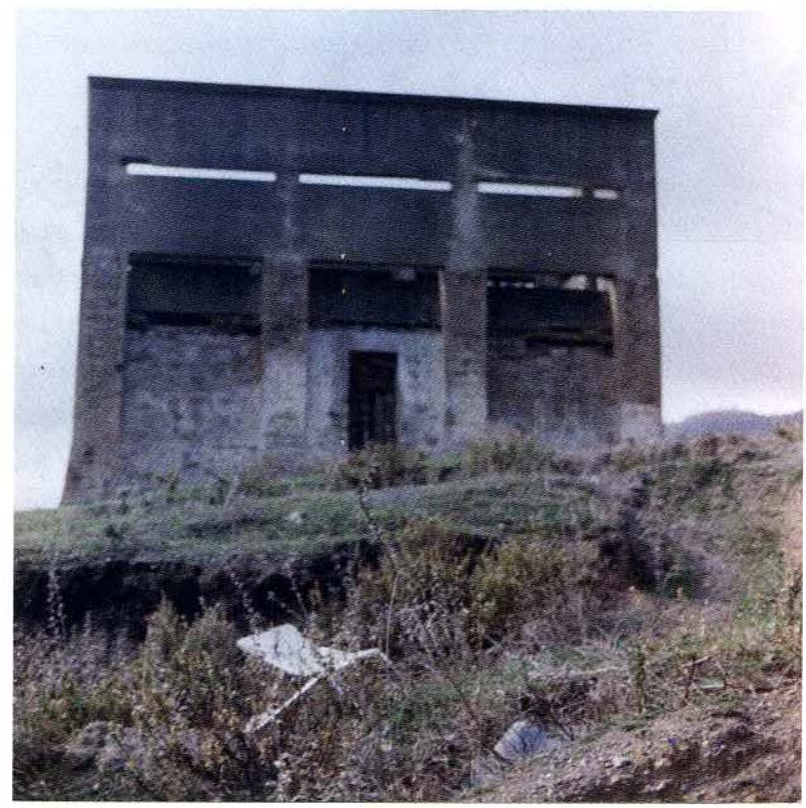

Una guardiana. Foto A. Orozco. Col. del autor.
De forma complementaria se construyeron otras pequeñas defensas, denominadas guardianas, con planta rectangular, manteniéndose algunas de las construcciones de campaña, modificadas o reforzadas, como el denominado reducto de la Estrella.

Los modelos neomedievales tuvieron gran éxito tras la Guerra de Africa, llegando a ser utilizados para levantar fortificaciones en el Hacho, los ya mencionados castillos del Desnarigado y el nunca terminado de Santa Catalina.

\section{EN EL PASO DEL SIGLO XIX AL XX}

Los conflictos coloniales que vivió España a finales del siglo XIX tuvieron su influencia en la defensa de Ceuta, en especial los temores a que Estados Unidos entrara en guerra con nuestro País.

26. Gómez Barceló, J.L., Bravo Nieto, A. y Bellver Garrido, J.A. Proyecto Arquitectura Neomedieval en Ceuta. Fuertes Exteriores- II, Instituto de Cultura Mediterránea para el Ministerio de Defensa. Melilla, 2005. 
Naturalmente, los peores momentos se vivieron a raíz de los sucesos de 1898 en los que una parte de la población huyó a la Península e incluso al Campo Exterior, creyéndose a salvo de posibles bombardeos, de lo que ha quedado testimonio en la prensa y la literatura local.

Así, la defensa por tierra pasó a tener entonces una importancia secundaria, reforzándose la artillería de costa, artillándose las baterías existentes y construyéndose otras nuevas. Las más importantes recibieron piezas Krupp y Ordóñez y de nuevo los ceutíes se acostumbraron al ruido de los cañones, aunque ahora, la mayor parte de las veces, su tiro era sólo de ejercicio, aunque seguían destrozando los cristales de las casas como si hubiera un ataque enemigo.

Toda esta artillería fue desapareciendo con el paso de los años, no siendo hoy más que un recuerdo en la memoria de la gente y la toponimia, así como una imagen frecuente en las colecciones fotográficas.

\section{EPÍLOGO: LA DEFENSA EN EL SIGLO XX}

\begin{abstract}
Si bien es cierto que la artillería de costa desplegada a comienzos de la centuria pasada sirvió para la alerta producida con la I Guerra Mundial, no lo es menos que con la Guerra Civil Española y la II Guerra Mundial el armamento había evolucionado y por tanto también fue necesario el cambio de la ceutí.
\end{abstract}

Se construyeron nu-

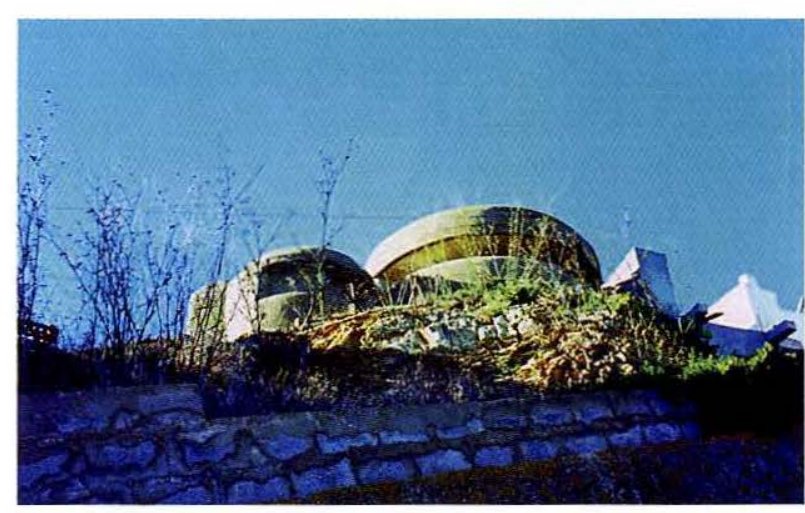

Bunker del Hacho. Foto J.J. Contreras Garrido. merosos bunkers y nidos de ametralladora, que en buena parte han ido desapareciendo en las últimas tres décadas, así como refugios antiaéreos para proteger a la población. Lamentablemente, y como sucedió en otro tiempo y lugares con la ingeniería militar abaluartada, no se ha hecho la suficiente fuerza como para defender su permanencia como parte del patrimonio militar de su tiempo. Cada vez son más difíciles de encontrar en las zonas exteriores de la población, mientras que en el interior van siendo absorbidos por las construcciones civiles. 


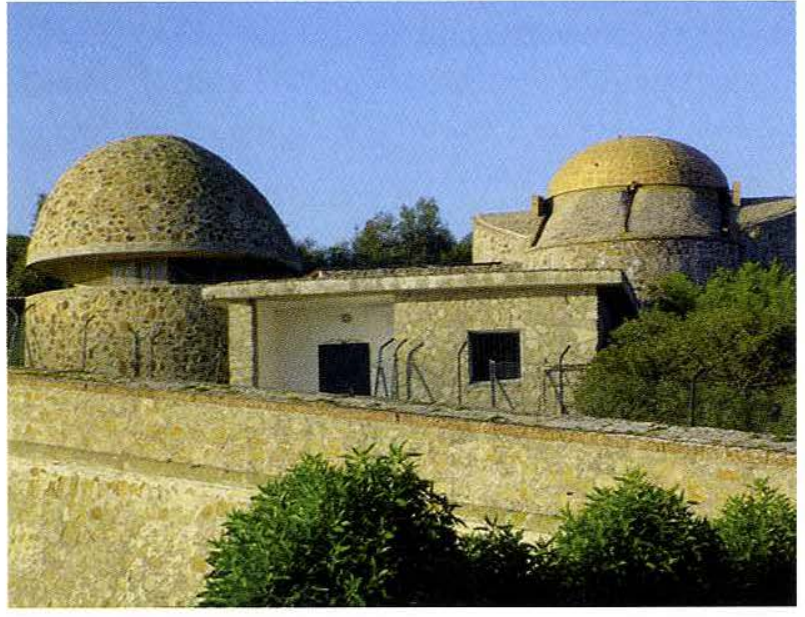

Bunker en el Recinto Sur. Foto del autor.
'Uno de los más interesantes es quizá el puesto de mando del Estrecho -la popular Tortuga-, levantado en lo que en los planos antiguos se denominaba la montaña del Marabut, el Renegado, para cuya construcción fue necesario demoler la torre neomedieval que existía en su lugar. Hoy ha perdido su uso y se encuentra abandonado y en ruinas, a pesar de contar con las vistas más impresionantes sobre el Estrecho de Gibraltar.

El último bunker con el que contó la Ciudad se construyó, como defensa antiaérea, dentro de la fortaleza del Hacho. Sus cúpulas móviles han sido una imagen sorprendente dentro de la enorme ciudadela, pero también ha perdido su uso en los últimos tiempos. La guerra, ahora, se hace de otra manera y con otras armas, sustrayéndonos quizá toda una tradición de ingeniería militar que va apasionando a los estudiosos de la historia del arte en proporción directa a su desaparición. 